\title{
An Effect Virgin Coconut Oil Oral And Topical On Volume Decrease Of Foot Edema Of Male Wistar Flows Induced By -Caragenan
}

\author{
Dzil Fikri ${ }^{1}$, Ermi Girsang ${ }^{2}$, Ali Napiah Nasution ${ }^{3}$, Linda Chiuman $^{4 *}$ \\ 1,2,3,4 Program Study Master Of Biomedical Science, School Of Medical, \\ Universitas Prima Indonesia Medan, North Sumatera, Indonesia \\ * Corresponding author: \\ Email: lindachiuman@unprimdn.ac.id
}

\begin{abstract}
.
Virgin Coconut Oil(VCO) is virgin coconut oil that is made enzymatically. The content of saturated fatty acids and flavonoid compounds in VCO can be used as an anti-inflammatory drug. This study aims to determine the activity of VCO as an anti-inflammatory. Anti-inflammatory activity was tested using the method of calculating the percentage of inflammation inhibition in white rat paws induced by intraplantar $1 \%$ carrageenan solution. The decrease in edema in the rat's feet was measured using a plethysmometer for 360 minutes. The results showed that VCO at a dose of $0.4 \mathrm{ml} / 200 \mathrm{~g} \mathrm{BW}$ and $0.8 \mathrm{ml} / 200 \mathrm{~g} \mathrm{BW}$ gave anti-inflammatory activity with the percentage of inflammation inhibition of $64.34 \pm 9.90$ and $52.66 \pm 8$, respectively. 94. The anti-inflammatory activity of VCO at a dose of 0.4 $\mathrm{ml} / 200 \mathrm{~g} \mathrm{BW}$ and a dose of 0 .
\end{abstract}

Keywords: Virgin Coconut Oil, Inflammation, Carrageenan, Plethismometer

\section{INTRODUCTION}

The use of plants as an herbal medicine has become increasingly popular in recent years. Medicinal plants are national assets that need to be explored, researched, developed, and optimized for use. The public's tendency to go back to nature, with the main indication of the increasing need for consumer products for health from natural ingredients, is an opportunity for the development of medicinal plants as traditional medicines (Ariningrum, 2003).Pure coconut oil better known as Virgin Coconut Oil (VCO) is a modification of the coconut oil manufacturing process so that it produces products with low water content and free fatty acid levels, is clear in color, smells good, and has a long shelf life of more than 12 months. The manufacture of virgin coconut oil has many advantages, namely, it does not require expensive costs because the raw materials are easy to obtain at low prices, the processing is simple and not too complicated, and the use of minimal energy because it does not use fuel so that the chemical and nutritional content is maintained, especially fatty acids in oil (Winarno, 2014).

One of the benefits shown by VCO is as an anti-bacterial. Inflammation is a localized protective response elicited by injury or tissue damage, which serves to destroy, reduce, or contain an injuring agent or the injured tissue. Acute inflammation is characterized by classic signs, namely: pain (dolor), heat (Kalor), redness (rubor), swelling (tumor), and loss of function (functionless). Histologically, it involves a complex series of events, which include dilatation of arteries, capillaries, and venules, accompanied by increased permeability to blood flow, exudation of fluids, including plasma proteins, and migration of leukocytes into the focus of inflammation. This response is caused by the release of mediators (histamine, serotonin, prostaglandins, kinins) which play a role in regulating, activating cells, both from the blood and tissues, and then symptoms can arise from the injured tissue (Soenarto, 2007). Based on the description above, the author conducted a study entitled.

\section{LITERATURE REVIEW.}

\subsection{Pure Coconut Oil}

Coconut trees have accompanied the life of the Indonesian people since the time of their ancestor's thousands of years ago. A coconut tree is a tree that has very high usability. Coconut trees, including the Palmae

\section{https://ijhp.net}


family, are tropical plants that are spread on the coast (original habitat). However, in the development of cultivation, finally, coconut trees can be found in the mountains. All parts of the coconut tree provide benefits for everyday life, including coconuts which are used as oil. eat coconut milk in vegetables. However, nowadays it has been discovered as a medicine. Coconut oil that is used as a medicine is usually called virgin coconut oil (VCO) (Sutarmi, 2005).

Coconut fruit is oval with varying sizes, depending on soil conditions, climate, and varieties. The outer color of coconuts also varies, from yellow to light green, and when ripe they turn brown. The structure of the coconut fruit consists of coir (35\%), fruit flesh (28\%), coconut water (15\%), shell (12\%), and several other parts. Almost all parts of the coconut can be used, but the flesh is the part that is most widely used for food and industrial raw materials (Setiaji and Surip, 2002).Pure coconut oil (Virgin Coconut Oil, VCO) is one of the processed products from coconut (Cocos nucifera) which does not undergo chemical changes. In order not to undergo a chemical change process, the extraction of coconut oil is carried out by a cold process. For example, by fermentation, inducement, centrifugation, heating not more than $60^{\circ} \mathrm{C}$, drying grated coconut quickly, and others (Sutarmi, 2005; Darmoyuwono, 2006). In Table 2.1, it can be seen that the VCO quality standards for several characteristics are based on SNI (7381:2008).

Table 1. Quality standard (Virgin Coconut Oil, VCO)

\begin{tabular}{|c|c|c|c|}
\hline No. & Test Type & Unit & Condition \\
\hline 1 & $\begin{array}{l}\text { Circumstances: } \\
1.1 \text { Smell } \\
1.2 \text { Flavor } \\
1.3 \text { Color } \\
\text { Water and compounds } \\
\text { evaporate } \\
\text { Saponification number }\end{array}$ & $\begin{array}{l}\% \\
\mathrm{Mg} \mathrm{KOH} / \mathrm{g} \\
\text { oil }\end{array}$ & $\begin{array}{l}\text { coconut special } \\
\text { fresh, not rancid } \\
\text { normal, typical } \\
\text { coconut oil } \\
\text { colorless } \\
\text { until pale } \\
0.2 \text { max } \\
250.07-260.67\end{array}$ \\
\hline $\begin{array}{l}4 \\
5 \\
6\end{array}$ & $\begin{array}{l}\text { Iodine number } \\
\text { Free fatty acids (calculated } \\
\text { as lauric acid) } \\
\text { Fatty acid: } \\
\text { 6.1 Caproic acid (C6:0) } \\
\text { 6.2 Caprylic acid (C8:0) } \\
6.3 \text { Capric acid (C10:0) } \\
\text { 6.4 Lauric acid (C12:0) } \\
\text { 6.5 Myristic acid (C14:0) } \\
\text { 6.6 Palmitic acid(C16:0) } \\
\text { 6.7 Stearic acid (C18) } \\
\text { 6.8 Oleic acid (C18:1) } \\
6.9 \text { Linoleic acid (C18:2) } \\
\text { 6.10 Linolenic acid (C18:3) }\end{array}$ & $\begin{array}{l}\text { G-iod/100 gram } \\
\%\end{array}$ & $\begin{array}{l}\text { ND-0.7 } \\
4.6-10.0 \\
5.0-8.0 \\
45.1-53.2 \\
16.8-21 \\
7.5-10.2 \\
2.0-4.0 \\
5.0-10.0 \\
1.0-2.5 \\
\text { ND-0.2 }\end{array}$ \\
\hline
\end{tabular}

VCO can be obtained from fresh coconut flesh. VCO is made of fresh old coconut. The processing process does not use materials chemical and high heating. In general, the manufacture of VCO is distinguished by the method dry and wet method. In the dry method, the flesh of the fruit is extracted without additional water, while in the wet method, the pulp of the coconut fruit was extracted with the addition of water to get coconut milk then processed into VCO (Syah, 2005).

\subsection{Cardiovascular Disease}

Coconut oil contains only a small amount of long-chain saturated fatty acids. Meanwhile, short and medium-chain fatty acids are not atherogenic because they are quickly absorbed into the liver and immediately metabolized. Long-chain saturated fatty acids must go through an emulsification process in the intestine before being absorbed and transported with the help of lipoproteins and can form deposits in various organs including 
coronary blood vessels. Coconut oil is very easy to digest and absorb and is quickly metabolized. The advantage of coconut oil is that it can increase good fats, namely, high-density lipoprotein (HDL) and high phenolic acid content can increase its ability to erode and destroy free radical activity thereby revealing its antioxidant properties (Subermaniam, 2015).A diet rich in extra virgin coconut oil strongly supports a reduction in WC (Waist circumference) and an increase in HDL-C concentrations and can help in secondary prevention for patients with CAD (Coronary artery disease) such as myocardial infarction and stable angina (Cardoso et al, 2015).

\subsection{Oxidative Stress Reduction}

Oxidative stress is an imbalance between antioxidants and pro-oxidants and can contribute to the pathogenesis of various diseases such as liver disease, cardiovascular disease, malignancy, metabolic disorders, health problems in pregnant women, fetal growth, and development, and others. Oxidative stress can be indicated by the increased formation of lipid peroxidation and protein oxidation products such as malonaldehyde (MDA), hydroperoxides, conjugated dienes, and protein carbonyls in serum and tissue.

They are formed from lipid peroxides and proteins in the cell membrane by the reaction of free radicals (hydroxyl radicals) with polyunsaturated fatty acids. (PUFA). This increase in lipid peroxide and protein oxide products can potentially lead to both micro and macrovascular complications. Flavonoids and polyphenols contained in coconut oil are responsible for antioxidant activity in the human body, such as superoxide dismutase (SOD), catalase, glutathione peroxidase (GSH-Px), glutathione (GSH), so that the concentration and lipid peroxidation in the liver can be overcome. . This beneficial effect can be attributed to the increased content of polyphenols, tocopherols and other antioxidants contained in VCO (Boemeke et al, 2015).

\section{METHODS}

This research was conducted experimentally at the Pharmacology laboratory of the University of North Sumatra from July to August 2019. This research method includes the preparation of VCO, phytochemical screening examination, preparation of experimental animals and testing of anti-inflammatory effects using the paw edema method.The tools used in this research include pletismometer, vernier scala, electric balance, animal balance, microscope (Olympus), incubator, water bath, syringe, oral sonde, mortar and stamper and glassware (Pyrex).Sampling is carried out purposively, which is determined on the basis of the consideration that the samples taken have the same characteristics with those studied (Sudjana, 2005). The sample used is VCO brand $\mathrm{X}$.The simplicia powder was weighed as much as $0.5 \mathrm{~g}$ then added $1 \mathrm{~mL}$ of $2 \mathrm{~N}$ hydrochloric acid and $9 \mathrm{~mL}$ of distilled water, heated on a water bath for 2 minutes, cooled and then filtered. The filtrate was used for the following experiments:

a. 3 drops of filtrate is added, 2 drops of Mayer's rectifier solution will form a white or yellow precipitate.

b. 3 drops of filtrate was added with 2 drops of Bouchardat's rectifier solution to form a brown-black precipitate.

c. 3 drops of filtrate were added with 2 drops of Dragendorff's rectifier solution to form a red or orange precipitate.

Alkaloids are declared positive if there is a precipitate or at least two or three of the above experiments (Depkes RI, 1995).A total of $10 \mathrm{~g}$ of simplicia powder was added to $10 \mathrm{~mL}$ of distilled water, boiled for 5 minutes and filtered in hot conditions. $5 \mathrm{~mL}$ of the filtrate obtained, added $0.1 \mathrm{~g}$ of magnesium powder, $1 \mathrm{~mL}$ of concentrated hydrochloric acid and $2 \mathrm{~mL}$ of amyl alcohol, shaken and allowed to separate. Positive flavonoids if there is a red yellow or orange color on the amyl alcohol layer (Farnsworth, 1996). Animals were grouped into 6 groups, each group consisting of 5 rats, namely a negative control group (no treatment), a positive control group (diclofenac sodium), a group of oral VCO test materials (dose $0.2 ; 0.4$ and $0.8 \mathrm{ml} / \mathrm{kg} \mathrm{bw}$ ) and $100 \%$ VCO (dosage $0.1 \mathrm{ml}$ ) topically.On the day of testing, each rat was marked on the tail and on the right leg of the rat and

$\underline{\text { https://ijhp.net }}$ 
then the animal was weighed. Then the rat's right foot was put into a cell containing a special fluid on the plethysmometer until the fluid rose to the upper limit line, then the pedal was held, the number was recorded on the monitor as the initial volume (Vo), i.e. the volume of the foot before being given the drug and induced by a solution. carrageenan. After that each rat given a suspension of the test material orally according to the group. One hour later, each mouse paw was injected intraplantar with $0.1 \mathrm{~mL}$ of $1 \%$-carrageenan solution.

In contrast to the topical VCO treatment, the rats were injected intraplantar first with $1 \%$-carrageenan. After 30 minutes, measurements were taken by immersing the mouse's paw in a plethysmometer cell containing a special liquid until the solution reached the upper limit line, and the pedal was held. Recorded numbers on the monitor. Changes in fluid volume that occur are recorded as the volume of the rat's paws (Vt). Measurements were taken every 30 minutes for 360 minutes. And each time the measurement of the cell solution is still sufficient until the red line or marking line at the top of the cell and the zero button on the main menu is pressed,Inflammation volume was the difference in the volume of the rat's paws after and before -carrageenan injection. At the time of measurement, the volume of fluid in the plethismometer cell is the same every time it is measured and the boundary marks on the mouse's feet must be clear, the mouse's feet must be submerged to the limit made (Juheini, 1990).

\section{ANALYZE AND RESULT}

\subsection{Virgin Coconut Oil (VCO)}

VCO contains compounds of saturated fatty acids and unsaturated fatty acids that help the body's metabolism (Novilla, et al., 2017). These compounds can be seen in Tables 2.

Table 2. The content of fatty acid compounds in VCO

\begin{tabular}{|l|c|c|}
\hline No & Percentage (\%) & Fatty acid \\
\hline 1 & 0.187 & Caproic Acid \\
\hline 2 & 1.12 & Octanoic Acid \\
\hline 3 & 0.54 & Cyclopropanpentanoic Acid \\
\hline 4 & 32.73 & Lauric Acid \\
\hline 5 & 28.55 & Myristic Acid \\
\hline 6 & 17.16 & Palmitic Acid \\
\hline 7 & 14.09 & Oleic Acid \\
\hline 8 & 5.68 & Stearic Acid \\
\hline
\end{tabular}

Table 3. The content of secondary metabolites in VCO

\begin{tabular}{|c|c|c|c|}
\hline No & Identification & Reactor & Results \\
\hline & \multirow{3}{*}{ Alkaloids } & Bouchardart & \\
\hline 1 & & Maeyer & + \\
\hline & & Wagner & F \\
\hline \multirow{4}{*}{2} & \multirow{4}{*}{ Flavonoids } & $\mathrm{FeCl} 35 \%$ & ++ \\
\hline & & $\mathrm{NaOH} 10 \%$ & $1++$ \\
\hline & & $\mathrm{H} 2 \mathrm{SO} 4(\mathrm{p}$ & ++ \\
\hline & & $\operatorname{Mg}(\mathrm{s})+\mathrm{HCl}(\mathrm{p})$ & ++ \\
\hline 3 & Tannins & $\mathrm{FeCl} 35 \%$ & \\
\hline 4 & Glycoside & Molish & ++ \\
\hline
\end{tabular}


International Journal of Health and Pharmaceutical

\begin{tabular}{|l|l|l|l|}
\multirow{3}{*}{5} & \multirow{2}{*}{ Saponins } & Aquadest & \\
\cline { 3 - 4 } & & Aquadest+Alcohol 96\% & \\
\cline { 3 - 4 } & & Aquadest+Alcohol 96\%+ $\mathrm{HCl} 2 \mathrm{~N}$ & \\
\hline 6 & Steroids \& Triterpenoids & Salkowsky & \\
\cline { 3 - 4 } & & Lieberman-Bouchardart & \\
& & &
\end{tabular}

The activity of VCO as an anti-inflammatory cannot be separated from the content of compounds contained in VCO. Unsaturated fatty acids in the form of oleic acid and linoleic acid and the content of flavonoids are strongly suspected to function as an anti-inflammatory (Intahphuak, et al., 2010; Rahman and Devi, 2017).

\subsection{Anti-Inflammatory Activity of Virgin Coconut Oil}

Inflammation is a normal protective response to tissue injury caused by physical trauma, damaging chemical agents, or microbiological agents. Inflammation is the body's response that arises to inactivate or damage invading organisms, eliminate irritants, and regulate the degree of tissue repair (Oktiwilianti, et al., 2015). Inflammation can be local and systemic, can also occur acutely and chronically which will cause pathological abnormalities. The inflammatory response is characterized by rubor (redness), calor (heat), dolor (pain), tumor (swelling), and impaired function (Sukmawati, et al., 2015). Treatment of inflammation can be done in two ways. The first relieves the pain that is felt and the second reduces inflammation or the inflammatory response using proven drugs known as anti-inflammatory (Sukmawati, et al., 2015). Antiinflammatory is a term for agents / drugs that work against or suppress the inflammatory process. The use of anti-inflammatory is needed to reduce the occurrence of inflammation (Oktiwilianti, et al., 2015).

In this study, the anti-inflammatory activity of Virgin Coconut Oil (VCO) was tested. According to Varma (2017), VCO has activity as an anti-inflammatory which has been proven through testing in vitro. Components of natural compounds contained in VCO become a strong reason VCO functions as an antiinflammatory (Novilla, et al., 2017). This study was conducted in vivo using experimental white rats which were divided into six groups. Each group was given different treatment. Group one was a negative control group that was not treated with the test material, group two was induced with $4.5 \mathrm{mg} / \mathrm{Kg} \mathrm{BW}$ of diclofenac sodium, group three was VCO $0.2 \mathrm{ml} / 200 \mathrm{~g}$ rats, group four was VCO $0.4 \mathrm{ml} / 200 \mathrm{~g}$ rats, and group four was VCO $0.4 \mathrm{ml} / 200$ g. group five VCO $0.8 \mathrm{ml} / 200 \mathrm{~g}$ rats, and group six VCO $0.1 \mathrm{ml}$ topically.Each experimental animal in each group was induced with $1 \%$ carrageenan solution intraplantar. Carrageenan is a linear polymer that is useful as an inductor of inflammatory events. The development of inflammation after injection of carrageenan can be described as a biphasic event, in which various mediators operate sequentially to produce an inflammatory response. Inflammation that occurs due to carrageenan is an acute non-immune reaction, which can be well observed (Widianti, 2017). Inflammation is measured by looking at changes in the size of the sole of the foot using a plestimometer, so that the percentage of inflammation and the percentage of inflammation inhibition can be calculated. The results of the percentage of inflammation can be seen in Figure 1. 


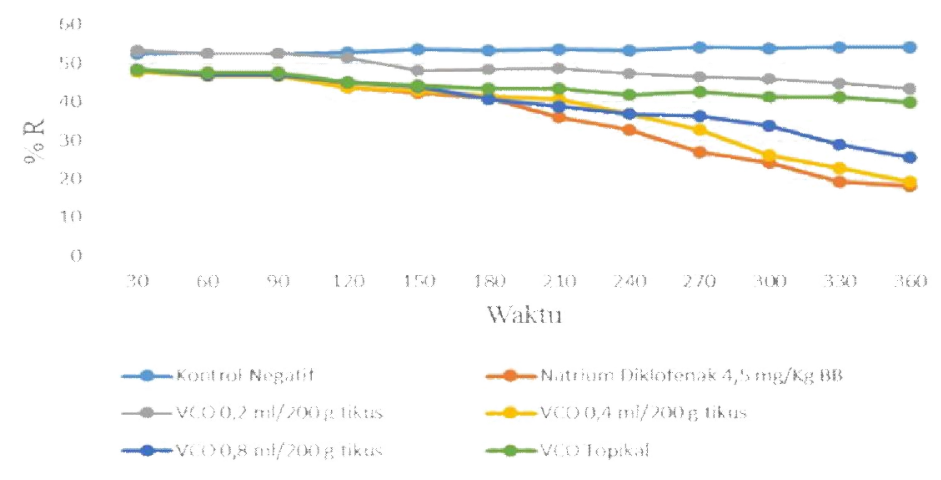

Fig 1. Percentage of foot inflammation of rats observed for 360 minutes after being induced with $1 \%$ carrageenan solution

Based on Figure 1, it can be explained that there was an increase in the percentage of inflammation in the negative control group immediately after being given carrageenan. While the test groups used diclofenac sodium $4.5 \mathrm{mg} / \mathrm{Kg} \mathrm{BW}$, VCO $0.2 \mathrm{ml} / 200 \mathrm{~g}$ rats, VCO $0.4 \mathrm{ml} / 200 \mathrm{~g}$ rats, VCO $0.8 \mathrm{ml} / 200 \mathrm{~g}$ rats. and VCO topically decreased the percentage of inflammation. This occurs due to the inhibition of the activity of inflammatory mediators such as bradykinin, histamine, and prostaglandins that arise in the tissue after being induced by carrageenan solution (Luliana, et al., 2017). Observations were made every 30 minutes for 360 minutes. During the observation, the highest percentage of inflammation appeared in the negative control group at 270 minutes of $54.32 \pm 2.93$. Meanwhile, the lowest percentage of inflammation occurred in the diclofenac sodium group $4.5 \mathrm{mg} / \mathrm{Kg} \mathrm{BW}$ in 360 minutes at $18.20 \pm 4.77$. The use of VCO with a dose of $0.2 \mathrm{ml} / 200 \mathrm{~g}$ rats, $0.4 \mathrm{ml} / 200 \mathrm{~g}$ rats, $0.8200 \mathrm{~g}$ rats and topically was stated to be able to inhibit inflammation because the percentage of inflammation continued to decrease from each. 


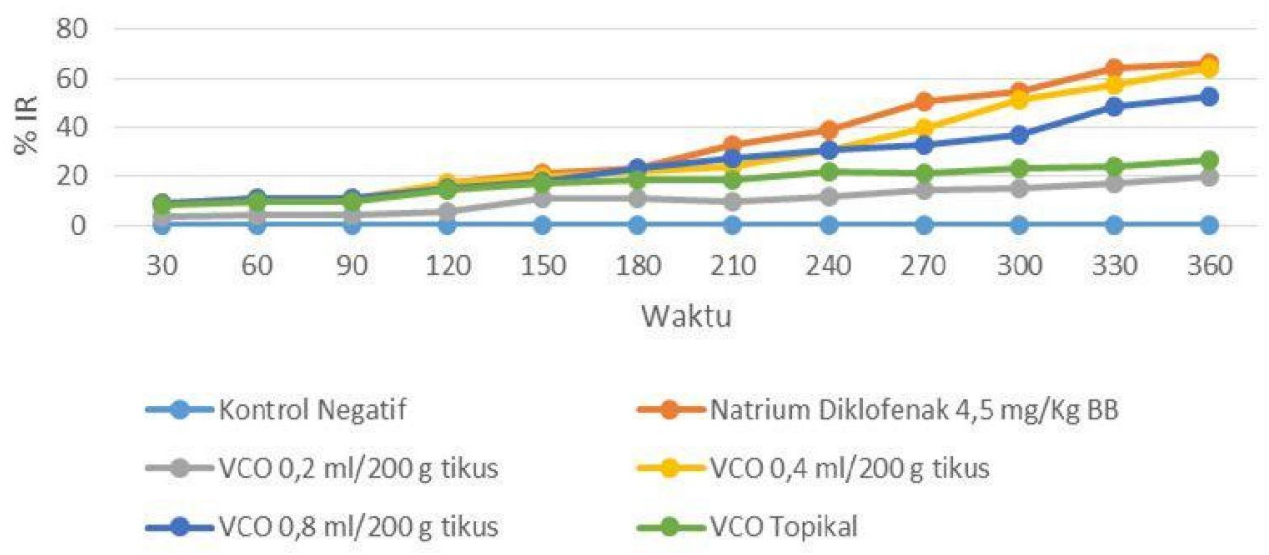

Fig 2. Percentage of inflammation inhibition observed for 360 minutes after administration of $1 \%$ carrageenan solution

The percentage of inflammation inhibition is a value that indicates the effectiveness of the test material in inhibiting inflammation, where the greater the percentage value of inflammation inhibition, the stronger the anti-inflammatory effect. Based on Figure 2, it can be explained that the negative control group had no inflammatory inhibitory activity at all, in contrast to the other groups, namely diclofenac sodium $4.5 \mathrm{mg} / \mathrm{Kg} \mathrm{BW}$, VCO $0.2 \mathrm{ml} / 200 \mathrm{~g}$ rats, VCO $0.4 \mathrm{ml} / 200 \mathrm{~g}$ rats, VCO $0.8 \mathrm{ml} / 200 \mathrm{~g}$ rats, and topical VCO which has inflammatory inhibitory activity. The greatest inflammation inhibition activity appeared in 360 minutes due to the administration of $4.5 \mathrm{mg} / \mathrm{Kg} \mathrm{BW}$ of diclofenac sodium in experimental animals of $66.45 \pm 8.79$. While the test materials were VCO $0.2 \mathrm{ml} / 200 \mathrm{~g}$ rats, VCO $0.4 \mathrm{ml} / 200 \mathrm{~g}$ rats, VCO $0.8 \mathrm{ml} / 200 \mathrm{~g}$ rats, and topical VCO at 360 minutes had inflammation inhibition percentages of $20.06 \pm 5.05$, respectively; $64.34 \pm 9.90 ; 52.66 \pm 8.94$; and $26.63 \pm 6.63$.

\section{CONCLUSION}

Based on the results of the research that has been done, it can be concluded:

a.VCO contains fatty acid compounds consisting of caproic acid, octanoic acid, cyclopropanpentamoic acid, lauric acid, myristic acid, palmitic acid, oleic acid, and stearic acid.

b. The results of the examination of the secondary metabolite compound found in VCO are flavonoids.

c.VCO doses of $0.2 \mathrm{ml} / 200 \mathrm{~g}$ body weight rats, $0.4 \mathrm{ml} / 200 \mathrm{~g}$ body weight rats and $0.8 \mathrm{ml} / 200 \mathrm{~g}$ body weight rats orally and $0.1 \mathrm{ml}$ VCO topically had an anti-inflammatory effect on male rats induced by $1 \%$-carrageenan solution intraplantar.

\section{REFERENCES.}

[1] Aggarwal, B., HSLamba., P. Sharma., Ajeet., 2017. Various Pharmacological Aspects of Cocos nucifera-A Review. American Journal of Pharmacological Science. 5(2): 25-30.

[2] Ahnan, AD, W. Agustinah., 2016. Effect of Virgin Coconut Oil Supplementation on Obese Rats Anthropometrical Parameters and Gut Bacteroidetes and Firmicutes Change Ratio. International Journal on Coconut R\&D. 32(1):1-57.

\section{https://ijhp.net}


[3] Anief, M. (1995). The Science of Compounding Drugs, Theory and Practice. V. Yogyakarta Printing: Gadjah Mada University Press. Page 107.

[4] Anzaku, AA, EBAssikong., A. Martin., U. Peter., TTKeneth., 2017. Antimicrobial Activity of Coconut Oil and Its Derivate (Lauric Acid) on Some Selected Clinical Isolates. International Journal of Medical Sciences and Clinical Inventions. 4 (8):3174-3177.

[5] Boemeke, L., A.Marcadenti., FMBusnello., GBAGottschall., 2015. Effects of Coconut Oil on Human Health. Open Journal of Endocrine and Metabolic Diseases. 5:84-87.

[6] Calder, PC (2006). N-3 Polyunsaturated Fatty Acids, Inflammation, and Inflammatory Diseases.The American Journal of Clinical Nutrition. 83(150): 1-19.

[7] Cardoso, DA, ASBMoreira., GMMOliveira., RRLuiz., G.Rosa, 2015. A Coconut Extra Virgin Oil-Rich Diet Increase HDL Cholesterol and Decreases Waist Circumference and Body Mass in Coronary Artery Disease Patients. Nutricion Hospitalaria. 32(5): 2144-2152.

[8] Darmoyuwono, W. (2006), Healthy Lifestyle With Virgin Coconut Oil.Jakarta: Publisher PT Index Gramedia Group. p.46.

[9] Indonesian Ministry of Health. (1995). Indonesian Medical Materials. Volume VI. Jakarta: Ministry of Health of the Republic of Indonesia. Pages 297-326,300-304.306.

[10] MOHRI. (1995). Indonesian Pharmacopoeia.Issue IV. Jakarta: Indonesian Ministry of Health. Page 7.

[11] FG Winarno, 2014. Medium Chain Triglyceride or MCT. In : Coconut tree of life. PT Gramedia Pustaka Utama, Jakarta 2014.

[12] Farnsworth, NR (1966). Biologycal and Phytochemical Screening of Plants. Journal of pharmaceutical science. Volume 55. Pages 262-264

[13] Ganiswarna, SG (1995). Pharmacology and Therapy. Edition IV. Jakarta: UI Press.Pages 208-209.

[14] Harborne, JB (1987). Phytochemical Method.Bandung: Publisher ITB Bandung. Pages 4-7.

[15] Intahphuak, S., Khonsung, P., and Panthong, A. (2010). Anti-inflammatory, Analgesic, and Antipyretic Activities of Virgin Coconut Oil. Pharmaceutical Biology. 48(2): 151-157.

[16] Juheini, FW, Mariana, Y., and Rusmawan, I. (1990). Anti-Inflammatory Effects of Ginger (Zingiber officinale. Rosc) Against Artificial Inflammation in White Rats. Indonesian Pharmacology and Therapeutic Magazine. 7(1):9-13.

[17] Kumar, P., N.Manjunatjh., M.Basil., K.Bhat., 2017. A Comparative Evaluation of The Effect of Virgin Coconut Oil And Chlorhexidine Mouthwash on Periodontal Pathogen-An Invitro Microbial Study". International Journal of Current Research. 9 (03): 48062-48067.

[18] Luliana, S., Ressi, S., and Ellya, A. (2017). Anti-inflammatory Activity Test of Ciplukan Herb Water Extract (Physalis angulata L) Against White Rat (Rattus novergicus L) Wistar Strain Induced by Carrageenan. Trad. Med. J. 22(3): 199-205.

[19] Nguyen, VTA, T, D. Le., HNPhan., LBTran., 2017. Antibacterial Activity of Free Fatty Acids from Hydrolyzed Virgin Coconut Oil Using Lipase from Candida rugosa. Hindawi Journal of Lipids. 2017: 1-7.

[20] Novilla, A., Perdina, N., and Wikan, M. (2017). Composition of Fatty Acids of Virgin Coconut Oil (Virgin Coconut Oil) With Potential As Anti-Candidiasis. EduChemia. 2(2): 161-173.

[21] Okiwilianti, W., Umi, Y., and Ratu, C. (2015). Anti-Inflammatory Activity Test of Ethanol Extract of Tamarind Leaves (Tamarindus indica L) Against Male Wistar Rats. Proceedings of the SPeSIA Unisba Research.

[22] Katzung, BG (2006). Basic and Clinical Pharmacology. Jakarta: EGC. page 573.

[23] Linnon, BL (2009). Phytochemical Screening And Anti-Inflammatory Effect Test of Ethanol Extract of Tempuyung Leaves (Sonchus arvensis L.) Against Inflammation in Rats. Thesis. Department of Pharmacy. USU. Medan. Pages 53-55.

[24] Mansjoer, S. (2003). Mechanisms of Anti-Inflammatory Drugs. Indonesian Pharmaceutical Media.7(1): 35-36. 